University of Nebraska - Lincoln

DigitalCommons@University of Nebraska - Lincoln

Nutrition and Health Sciences -- Faculty

Publications

Nutrition and Health Sciences, Department of

$3-2000$

\title{
Serum Lipid Response to n-3 Fatty Acid Enriched Eggs in Persons with Hypercholesterolemia
}

Nancy M. Lewis

University of Nebraska--Lincoln, nlewis2@unl.edu

Kim Schalch

University of Nebraska-Lincoln

Sheila E. Scheideler

University of Nebraska-Lincoln, spurdum2@unl.edu

Follow this and additional works at: https://digitalcommons.unl.edu/nutritionfacpub

Part of the Dietetics and Clinical Nutrition Commons

Lewis, Nancy M.; Schalch, Kim; and Scheideler, Sheila E., "Serum Lipid Response to n-3 Fatty Acid Enriched Eggs in Persons with Hypercholesterolemia" (2000). Nutrition and Health Sciences -- Faculty Publications. 16.

https://digitalcommons.unl.edu/nutritionfacpub/16

This Article is brought to you for free and open access by the Nutrition and Health Sciences, Department of at DigitalCommons@University of Nebraska - Lincoln. It has been accepted for inclusion in Nutrition and Health Sciences -- Faculty Publications by an authorized administrator of DigitalCommons@University of Nebraska - Lincoln. 


\title{
Serum Lipid Response to n-3 Fatty Acid Enriched Eggs in Persons with Hypercholesterolemia
}

\author{
Nancy M. Lewis PhD, RD, FADA, ${ }^{1}$ Kim Schalch MS, RD, ${ }^{2}$ and Sheila E. Scheideler PhD ${ }^{1}$ \\ 1. N. M. Lewis is an associate professor in the Department of Nutritional Science and Dietetics, and S. E. Scheideler is a professor in the De- \\ partment of Animal Science at the University of Nebraska, Lincoln, USA. \\ 2. K. Schalch is a dietitian in Lincoln, Neb. At the time of the study, she was a graduate research assistant in the Department of Nutritional \\ Science and Dietetics at the University of Nebraska, Lincoln, USA. \\ Corresponding author - Nancy M. Lewis, PhD, RD, FADA, 316 RLH, University of Nebraska, Lincoln, NE 68583.
}

C onsumption of long-chain n-3 polyunsaturated fatty acids (n-3 PUFA) is low among certain population subgroups in the United States, especially in people living in Midwestern states and those who dislike fish $(7,8)$. Therefore, there is a need to identify acceptable food sources of n-3 PUFA. Vegetable oils, such as canola and soy, provide some n-3 fatty acids. However, these sources are high in n-6 fatty acids and there is concern that they may have detrimental side effects (9). Eggs enriched in n-3 PUFA can be produced by incorporating sources of these fatty acids into poultry rations $(10,11)$. In acceptability studies, US consumers responded positively to n-3 enriched eggs (12). However, Americans may be reluctant to consume eggs as a source of n-3 PUFA because of their cholesterol content.

Dietary intake of n-3 PUFA is associated with a reduced risk of primary cardiac arrest and sudden and nonsudden death (1-4). The plantbased form of n-3 PUFA, á linolenic acid (LNA, 18:3n-3), may also reduce coronary heart disease (5). Harris (6) suggests that the effects of LNA and n6 fatty acids on serum lipids are similar, whereas marine n-3 PUFAs appear to raise low-density lipoprotein (LDL) and high-density lipoprotein levels and reduce serum triglycerides. The n-3 PUFAs may have positive effects on serum lipids. Consumption of a large dose (20 g/day) of n-3 PUFA from fish oil significantly reduced both serum triglycerides and total serum cholesterol in patients with hyperlipidemia (13). Oh et al (14) reported that persons with normal lipid levels who consumed 4EPA and DHA-enriched eggs per day reduced their serum triglyceride and blood pressure levels, but there was no effect on total serum cholesterol. People with normal lipid levels who consumed 4 LNA-enriched eggs per day experienced no signif- icant effects on either serum triglycerides or total serum cholesterol (15). There is a need to further assess the role of eggs as a source of n-3 PUFA in the US diet. The purpose of this study was to evaluate the effects of the addition of LNA- and DHA-enriched eggs on serum lipids of people with hyperlipidemia who were consuming a lowfat diet.

\section{Methods}

Twenty-five volunteers with hypercholesterolemia (serum cholesterol $>5.2 \mathrm{mmol} / \mathrm{L}^{*}$ ) were recruited from the community. The participants -13 men and 12 women-ranged in age from 26 to 73 years. None of the volunteers had been diagnosed with any disease (including heart disease). The project was approved by the Institutional Review Board at the University of Nebraska, Lincoln. Volunteers were randomly assigned to 3 experimental treatments: a low fat, self selected diet with no eggs (no egg); a low-fat self-selected diet with 12 n-3 PUFAenriched eggs per week (omega egg); and a low-fat, self-selected diet with 12 control eggs per week (control egg). A low-fat diet was defined as $<30 \%$ of energy from fat and $<10 \%$ of energy from saturated fat. A Latin square design was used so that all volunteers received each treatment during the 38week study. A 2-week baseline period was followed by a 6-week, low-fat, lead-in period before the first 6-week diet treatment began. The order of the diet treatments was randomized. Sixweek, low-fat, washout periods-during which no eggs were consumedwere used between diet treatments.

After the baseline period, volunteers received nutrition counseling on the low-fat diet by a registered dietitian once every 2 weeks. Body weight was also monitored at each 2-week appointment. Volunteers received detailed instruction on estimating serv- ing sizes and keeping complete food records. They provided 3-day food records twice during each period (weeks 3 and 6). Week 3 food records were used for monitoring and week 6 records were included in the data analysis. Food records were checked for completeness and analyzed using the Food Processor Plus computer program (ESHA version 6.0, Salem, Ore). Mean daily energy, fat, and cholesterol consumption were determined for each period. Blood samples were drawn from fasting subjects twice during each period (weeks 4 and 6) and serum lipid levels were determined immediately at a certified medical laboratory (Nickols Institute, Lincoln, $\mathrm{Neb)}$ using standardized laboratory procedures.

The Department of Animal Science at the University of Nebraska, Lincoln, produced the eggs consumed during the omega-egg and control-egg treatment periods. The n-3 PUFA-enriched eggs were produced by including flaxseed in the poultry ration (12). The n-3 PUFA content of the control egg was $65 \mathrm{mg} / \mathrm{egg}$ and this increased to $412 \mathrm{mg} /$ egg in the n-3 PUFA-enriched egg. The majority of the increase in $n-3$ PUFA in the enriched egg was from LNA, which increased from $17 \mathrm{mg} /$ egg in the control egg to $277 \mathrm{mg} / \mathrm{egg}$ in the n-3 PUFA-enriched egg. The DHA content of the n-3 PUFA-enriched egg also increased from $35 \mathrm{mg} /$ egg in the control egg to $114 \mathrm{mg} / \mathrm{egg}$ in the n-3 PUFA-enriched egg.

The mean of the 2 serum samples obtained from each volunteer during each treatment period was used for data analysis. The general linear model procedure of SAS (version 6, 1994, SAS Institute, Gary, NC) was used to compare treatment means using a repeated-measures analysis of variance. Statistical analyses were also used to identify if any treatment ordereffect was present. Mean change from 
Table 1. Mean $\left( \pm \mathrm{SEM}^{\mathrm{a}}\right)$ serum lipids ${ }^{\mathrm{b}}$ of volunteers consuming a no egg, $n-3$ PUFA $^{c}$-enriched egg, or control egg low-fat ${ }^{d}$ diet treatment

\begin{tabular}{|c|c|c|c|c|c|c|}
\hline \multirow[t]{2}{*}{ Serum lipids } & \multicolumn{2}{|c|}{ No egg } & \multicolumn{2}{|c|}{$n-3$ egg $^{e}$} & \multicolumn{2}{|c|}{ Control egg } \\
\hline & $\begin{array}{l}\text { Nonresponders } \\
(n=23)\end{array}$ & $\begin{array}{l}\text { Nonresponders } \\
\text { and responders } \\
(n=25)\end{array}$ & $\begin{array}{l}\text { Nonresponders } \\
(n=23)\end{array}$ & $\begin{array}{l}\text { Nonresponders } \\
\text { and responders } \\
(n=25)\end{array}$ & $\begin{array}{l}\text { Nonresponders } \\
(n=23)\end{array}$ & $\begin{array}{l}\text { Nonresponders } \\
\text { and responders } \\
(n=25)\end{array}$ \\
\hline \multicolumn{7}{|l|}{ Cholesterol $(\mathrm{mmol} / \mathrm{L})^{\mathrm{g}}$} \\
\hline Total & $5.92 \pm 0.07$ & $5.90 \pm 0.07$ & $\begin{array}{l}6.00 \pm 0.06 \\
0.08 \pm 0.20^{h}\end{array}$ & $\begin{array}{l}6.06 \pm 0.07 \\
0.16 \pm 0.20\end{array}$ & $\begin{array}{l}5.92 \pm 0.07 \\
0.00 \pm 0.20\end{array}$ & $\begin{array}{l}5.97 \pm 0.07 \\
0.07 \pm 0.20\end{array}$ \\
\hline LDL & $3.88 \pm 0.06$ & $3.87 \pm 0.06$ & $\begin{array}{l}4.09 \pm 0.06 \\
0.21 \pm 0.17\end{array}$ & $\begin{array}{l}4.16 \pm 0.06^{* *} \\
0.29 \pm 0.17\end{array}$ & $\begin{array}{l}3.98 \pm 0.06 \\
0.10 \pm 0.17\end{array}$ & $\begin{array}{l}4.05 \pm 0.06^{* *} \\
0.18 \pm 0.17\end{array}$ \\
\hline HDL & $1.24 \pm 0.02$ & $1.22 \pm 0.02$ & $\begin{array}{l}1.24 \pm 0.02 \\
0.00 \pm 0.06\end{array}$ & $\begin{array}{l}1.21 \pm 0.02 \\
0.01 \pm 0.06\end{array}$ & $\begin{array}{l}1.26 \pm 0.02 \\
0.02 \pm 0.06\end{array}$ & $\begin{array}{l}1.23 \pm 0.02 \\
0.01 \pm 0.06\end{array}$ \\
\hline Triglycerides (mmol/L) ${ }^{\mathrm{i}}$ & $1.73 \pm 0.09$ & $1.76 \pm 0.08$ & $\begin{array}{l}1.46 \pm 0.09 \\
0.27 \pm 0.25\end{array}$ & $\begin{array}{l}1.50 \pm 0.09^{*} \\
0.26 \pm 0.23\end{array}$ & $\begin{array}{l}1.59 \pm 0.09^{*} \\
0.14 \pm 0.25\end{array}$ & $\begin{array}{l}1.60 \pm 0.08 \\
0.16 \pm 0.23\end{array}$ \\
\hline $\begin{array}{l}\text { a. SEM=standard error } \\
\text { b. Mean of } 2 \text { serum sa } \\
\text { c. PUFA=polyunsatura } \\
\text { d. Low-fat diet }=<30 \% \\
\text { e. } 12 \mathrm{n}-3 \text { fatty acid-en } \\
\text { f. } 12 \text { standard eggs pe } \\
\text { g. To convert } \mathrm{mmol} / \mathrm{L} \\
\text { Cholesterol of } 5.00 \\
\text { h. Difference from no } \\
\text { i. To convert } \mathrm{mmol} / \mathrm{L} t \\
\text { Triglyceride of } 1.8 \\
\text { * } P<.05 \text { (omega egg } \\
\text { ** } P<.01 \text { (no egg vs }\end{array}$ & $\begin{array}{l}\text { e mean. } \\
\text { s obtained at week } \\
\text { tty acid. } \\
\text { nergy as fat, < } 10 \% \\
\text { d eggs per week. } \\
\text { k. } \\
\text { sterol to } \mathrm{mg} / \mathrm{dL} \text {, } \mathrm{m} \\
\mathrm{o} / \mathrm{L}=193 \mathrm{mg} / \mathrm{dL} \text {. } \\
\mathrm{SEM} \text {. } \\
\text { eride to } \mathrm{mg} / \mathrm{dL} \text {, m } \\
\text { ol/L=159 } \mathrm{mg} / \mathrm{dL} \text {. } \\
\text { ntrol egg). } \\
\text { a egg and control }\end{array}$ & $\begin{array}{l}4 \text { and } 6 \text { of each } p \\
\text { of energy as satur } \\
\text { ultiply } \mathrm{mmol} / \mathrm{L} \text { by } \\
\mathrm{DL}=\text { low-density lip } \\
\text { ltiply } \mathrm{mmol} / \mathrm{L} \text { by } 8\end{array}$ & $\begin{array}{l}\text { riod. } \\
\text { ted fat. } \\
\text { 38.7. To convert } \\
\text { oprotein. HDL=h } \\
\text { 8.6. To convert m }\end{array}$ & $\begin{array}{l}\mathrm{gg} / \mathrm{dL} \text { cholestero } \\
\text { gh-density lipop } \\
\mathrm{g} / \mathrm{dL} \text { triglyceride }\end{array}$ & $\begin{array}{l}\mathrm{mmol} / \mathrm{L} \text {, multipl } \\
\text { ain. } \\
\mathrm{mmol} / \mathrm{L} \text {, multiply }\end{array}$ & mg/dL by 0.026 . \\
\hline
\end{tabular}

Table 2. Dietary fat intake ${ }^{a}$ (mean $\pm S E M^{b}$ ) of volunteers consuming a self-selected low-fat ${ }^{c}$ diet with no eggs, $n$-3 fatty acidenriched eggs or control eggs added $(n=25)$

\begin{tabular}{lccc}
\hline Dietary fat & & Diet Treatment & \\
\cline { 2 - 4 } & No egg & $\mathrm{n}-3$ egg $^{\text {d }}$ & Control egg $^{\text {b }}$ \\
\hline Total fat (\% of energy) & $21.5 \pm 0.64^{\mathrm{XZ}}$ & $24.1 \pm 0.68$ & $24.5 \pm 0.67$ \\
Saturated fatty acids (\% of energy) & $6.60 \pm 0.25^{\mathrm{y}}$ & $7.30 \pm 0.26$ & $7.86 \pm 0.26$ \\
Monounsaturated fatty acids (\% of energy) & $7.19 \pm 0.29^{\mathrm{XZ}}$ & $8.97 \pm 0.32$ & $9.32 \pm 0.31$ \\
Polyunsaturated fatty acids (\% of energy) & $5.07 \pm 0.26$ & $5.56 \pm 0.28$ & $4.93 \pm 0.28$ \\
n-3 Fatty acids (mg/d) & $620 \pm 71^{\mathrm{X}}$ & $1,420 \pm 76^{\mathrm{Y}}$ & $658 \pm 75$ \\
Cholesterol (mg/d) & $142 \pm 17.8^{\mathrm{XZ}}$ & $468 \pm 19.1$ & $481 \pm 18.8$ \\
\hline
\end{tabular}

a. Mean of 3 days obtained at week 6 of each period.

b. SEM=standard error of the mean.

c. Low-fat diet $=<30 \%$ of energy as fat, $<10 \%$ of energy as saturated fat.

d. 12 n-3 fatty acid-enriched eggs/week.

e. 12 standard eggs/week.

x. Different from n-3 egg $P<.05$

y. Different from control egg $P<.0001$

z. Different from control egg $P<.05$ 
no egg to either n-3 egg or standard egg was calculated.

\section{Results and Discussion}

Analysis of diet records indicated that all 25 volunteers maintained a low-fat diet throughout the treatment and washout periods. Overall mean daily total consumption and saturated fat consumption for the 36 weeks were $22 \%$ and $7 \%$ of energy, respectively. Mean daily cholesterol consumption was $142 \pm 18 \mathrm{mg} /$ day on the noegg treatment and $475 \pm 19 \mathrm{mg} /$ day on the omega-egg and control-egg treatments combined. Initial body mass index of the volunteers was $25.7 \pm 2.9$ (mean \pm SD) and results of weight monitoring indicated that this did not change throughout the study. Analysis indicated that the order in which the treatments were given had no effect. Two subjects did not have blood samples for one treatment period. The statistical analysis used accounts for these missing data. Two volunteers responded to the egg treatments with an increase in total serum cholesterol that was beyond 2 standard deviations of the group mean. Data from these 2 volunteers were omitted from the column labeled "Nonresponders $(\mathrm{n}=23)$ " in Table 1 but were included in the column labeled "Non responders and responders $(\mathrm{n}=25) . "$

There were no significant differences in the effects of the dietary treatments on any of the serum lipids in the nonresponders. However, when data from responders were added to the analysis, there was a significant increase in LDL cholesterol with the egg treatments $(P<.01)$. There was a $7 \%$ increase in LDL cholesterol when omega eggs were added and a 5\% increase when control eggs were added. For the 2 responders with the high total serum cholesterol increase alone, corresponding increases in LDL cholesterol were $26 \%$ for omega eggs and $22 \%$ for control eggs (data not shown). Other researchers have also found that there is a certain subset of the population that is responsive to dietary cholesterol and will therefore respond to an increase in dietary cholesterol with an increase in total and LDL serum cholesterol levels (16).

The most substantial change in serum lipid levels was in serum triglyceride levels, which were $16 \%$ lower on the omega-egg diet treatment than on the no-egg treatment. When responders $(n=25)$ were added to the data analysis, the difference in the decline in serum triglycerides on the 2 types of eggs became significant $(P<.05)$. The drop in serum triglycerides from the no-egg treatment was $15 \%$ on the omega-egg treatment and $9 \%$ on the control-egg treatment.

Table 2 shows the effect on fat intake of the addition of the 12 eggs per week. When eggs were added to the low-fat diet, total fat, monounsaturated fatty acids, and cholesterol significantly increased $(P<.05)$. Saturated fat intake increased significantly on the control-egg treatment but not on the omega-egg treatment. When volunteers consumed the omega-egg dietary treatment, the intake of $n-3$ PUFA more than doubled.

\section{Applications}

Results of this research indicate that the majority of people with hypercholesterolemia who are consuming a step 1 diet can add 12 eggs per week without experiencing a significant increase in serum total or LDL cholesterol levels. However, a subset of this population is sensitive to dietary cholesterol and their serum total and LDL cholesterol levels will increase with egg consumption.

- The addition of 2 n-3 PUFA enriched eggs per day as part of a low-fat diet increases the total n-3 PUFA intake to approximately $1.4 \mathrm{~g} /$ day. If n-3 PUFA-enriched eggs are recommended as a mechanism for increasing n-3 PUFA in the diet, serum cholesterol must be checked to ensure that the patient does not respond to the additional dietary cholesterol. Dietetics professionals can monitor the response of their patients to the addition of eggs by taking a pre and postmeasurement of serum cholesterol approximately 1 month apart.

- The n-3 enriched egg is an affordable food source of n-3 PUFAs that is acceptable and easy to prepare for most people. Three n-3 PUFA-enriched eggs provide approximately the same amount of $\mathrm{n}-3$ fatty acids as one fish meal (equivalent to $3 \mathrm{oz}$ fish). The number of n-3 PUFA-enriched eggs recommended for a person will vary with his or her current n-3 PUFA intake. It is recommended that $n-3$ PUFA-enriched eggs be used as one source of n-3 PUFA to increase individual consumption, particularly in people who seldom eat fish.

\section{References}

1. Albert, C.M., Hennekens, C.H., O'Donnell, C.J., Ajani, U.A., Carey, V.J., Willet, W.C., Ruskin, J.N. and Manson, J.E., Fish consumption and risk of sudden cardiac death. JAMA. 279, pp. 23-28.
2. Daviglus, M.L., Stamler, J., Orencia, A.J., Dyer, A.R., Liu, K., Greenland, P., Walsh, M.K., Morris, D. and Shekelle, R.B., Fish consumption and the 30-year risk of fatal myocardial infarction. N Engl J Med. 336, pp. 1046-1053.

3. Siscovick, D.S., Raghunathan, T.E., King, I., Weinmann, S., Wicklund, K.G., Albright, J., Bovbjerg, V., Arbogast, P., Smith, H., Kushi, L.H., Cobb, L.A., Copass, M.K., Psaty, B.M., Lemaitre, R., Retzlaff, B., Childs, M. and Knopp, R.H., Dietary intake and cell membrane levels of longchain n-3 polyunsaturated fatty acids and the risk of primary cardiac arrest. JAMA. 274, pp. 1363-1367.

4. Nordoy, A., Bonaa, K.H., Nilsen, H., Berge, R.K., Hansen, J.B. and Ingebretsen, O.C., Effects of Simvastatin and omega-3 fatty acids on plasma lipoproteins and lipid peroxidation in patients with combined hyperlipidaemia. J Intern Med. 243, pp. 163-170.

5. de Lorgeril, M., Renaud, S., Mamelle, N., Salen P., Martin, J.L., Monjaud, I., Guidollet, J., Touboul, P. and Delaye, J., Mediterranean alpha-linolenic acid-rich diet in secondary prevention of coronary heart disease. Lancet. $\mathbf{3 4 3}$ pp. 1454-1459.

6. Harris, W.S., n-3 Fatty acids and serum lipoproteins: human subjects. Am J Clin Nutr. 65 suppl, pp. 1645S-1654S

7. Lewis, N.M., Widga, A.C., Buck, J.S. and Frederick, A.M., Survey of omega-3 fatty acids in diets of midwest lowincome pregnant women. $J$ Agromedicine. 2, pp. 49-57.

8. Lewis, N.M., Albrecht, J.A., Schnepf, M.I., Hamouz, F.L., Driskell, J.A. and Goertz, J.A., Meat choices and cookery methods of Nebraskans. J Foodservice Systems. 8, pp. 165-174.

9. Kelly, F.J., The metabolic role of $n-3$ polyunsaturated fatty acids: relationship to human disease. Comp Biochem Physiol. 98A, pp. 581-585.

10. Herber, S.M. and Van Elswyk, M.E., Dietary marine algae promotes efficient deposition of n-3 fatty acids for the production of enriched shell eggs. Poul Sci. 75, pp. 1501-1507.

11. Van Elswyk, M.E., Designer foods: manipulating the fatty acid composition of meat and eggs for the health conscious consumer. Nutr Today. 28, pp. 21-27.

12. ScheidelerSE, Froning G, Cuppett, S., Studies of consumer acceptance of high omega-3 fatty acid-enriched eggs. J Appl Poult Res. 6, pp. 137-146.

13. Phillipson, B.E., Rothrock, D.W., Connor, W.E., Harris, W.S. and Illingworth, D.R., Reduction of plasma lipids, lipoproteins, and apoproteins by dietary fish oils in patients with hypertriglyceridemia. N Engl J Med. 312, pp. 1210-1216.

14. Oh, S.Y., Ryue, J., Hsieh, C. and Bell, D.E., Eggs enriched in omega-3 fatty acids and alterations in lipid concentrations in plasma and lipoproteins and in blood pressure. Am J Clin Nutr. 54, pp. 689-695.

15. Ferrier, L.K., Caston, L.J., Leeson, S., Squires, J., Weaver, B.J. and Holub, B.J., Alpha-linolenic acid- and docosahexaenoic acid-enriched eggs from hens fed flaxseed: influence on blood lipids and platelet phospholipid fatty acids in humans. Am J Clin Nutr. 62, pp. 81-86.

16. Katan, M.B. and Beynen, A.C., Characteristics of human hypo- and hyperresponders to dietary cholesterol. Am J Epidemiol. 125, pp. 387-399.

Acknowledgments - Partial funding was provided by the Agricultural Research Division of the University of Nebraska-Lincoln (Journal Series No. 12264), the North Dakota Oilseed Council, and the US Poultry and Egg Association. 